\title{
0 pensamento político de Maquiavel e o nacional popular: análise sobre os Quaderni de Antonio Gramsci
}

\author{
The political thought of Machiavelli and the "popular national": \\ analysis about Antonio Gramsci's Quaderni
}

\author{
Claudio Reis \\ Doutor em Ciências Sociais, Universidade Estadual de \\ Campinas - UNICAMP, Professor de Ciência Política, \\ Universidade Federal da Grande Dourados - UFGD \\ e-mail: claudio.reiss@yahoo.com.br
}

Recebido: 26/09/2012

Aceito: 20/02/2013
RESUMO No interior dos Quaderni del carcere, principal trabalho de Antonio Gramsci, é possível encontrar uma série de reflexões importantes sobre o fundador do moderno pensamento político, isto é, Nicolau Maquiavel. E dentro das discussões encontradas no texto gramsciano, aqui, será privilegiada aquela correspondente à relação entre o florentino e a questão nacional. O objetivo, portanto, é demonstrar como Gramsci introduz a temática da unificação italiana à teoria política maquiavelina.

PALAVRAS-Chave Antonio Gramsci; Quaderni del carcere; Maquiavel; Nacional popular.

ABSTRACT In Quaderni del carcere, the main work of Antonio Gramsci, there are important considerations about the founder of the modern political thought, Niccolò Machiavelli. The current study focuses on the relation between the Florentine and the national issue presented in the Gramsci's work. Therefore, the objective is to demonstrate how Gramsci relates the Italian unification and the Machiavelli's political theory.

KEYWORDS Antonio Gramsci; Quaderni del carcere; Machiavelli; "national-popular".

\section{Introdução}

Entre os diversos temas abordados nos Quaderni del carcere, um que certamente merece destaque corresponde à questão nacional. Mesmo não tendo dedicado a ela nenhum dos chamados "cadernos especiais", Gramsci aborda constantemente o problema da nação. O tema está inserido em várias outras discussões: sobre os intelectuais, sobre a hegemonia, sobre o partido político, sobre a cultura, entre outros; em todas essas questões, o autor, em algum momento da reflexão, faz referência ao problema nacional italiano. Ora de maneira rápida e elementar, ora de forma profunda e complexa, é possível encontrar nos Quaderni um conjunto de ideias sobre a temática. Como resultado desse trabalho - não somente no âmbito do marxismo, mas nas ciências sociais 
como um todo - Gramsci pode ser considerado como um autor bastante original quanto à abordagem da questão nacional. E ainda que privilegiando a análise do caso italiano, suas ideias acabaram contribuindo para o entendimento de outros contextos.

Do mesmo modo, como se sabe, uma das pesquisas mais aprofundadas nesse trabalho desenvolvido na prisão pelo sardo/italiano, corresponde a analise sobre o pensamento de Nicolau Maquiavel - considerado fundador da moderna ciência política. Na verdade, o florentino é uma das grandes referências intelectuais de Gramsci, como é possível perceber nos textos carcerários. Por sua vez, para a ciência política contemporânea, as notas gramscianas sobre a obra de Maquiavel, também trazem significativas contribuições.

No caso da questão nacional italiana, segundo indicações do próprio Gramsci, Maquiavel será o primeiro a sistematiza-la politicamente. Mesmo estando no contexto renascentista, definido pelo autor dos Quaderni como um movimento reacionário do ponto de vista nacional e popular, o secretário florentino chamará a atenção para o problema tanto da fragmentação política e territorial da península, quanto, em consequência disso, do domínio de potencias estrangeiras sobre os italianos. Em Maquiavel, Gramsci encontra uma primeira problematização teórica acerca da situação fragmentária não apenas geográfica, mas também sócio-política vivida pelos italianos.

Por esses motivos que as notas sobre o pensamento político de Maquiavel podem ser consideradas como uma chave interpretativa fundamental da questão nacional italiana nos Quaderni.

\section{Maquiavel e a política}

Em $O$ Príncipe, tem-se a nítida impressão de que Maquiavel está preocupado em não escrever um tratado político qualquer, mas sim um que tenha como base a própria realidade histórica - sem construções retóricas e sem criações arbitrárias de um ponto de vista intelectual. Em outras palavras, o autor não se propôs a escrever um texto descolado da vida concreta, como o próprio afirma:

[...] esta obra, eu não a ornei nem a enchi de períodos longos ou de palavras empoladas e magnificentes, ou de qualquer outro artifício de arte ou ornamento extrínseco, com os quais muita gente costuma descrever e ornar as suas coisas; porque não quis que artifício algum lhe valesse, mas, sim, que apenas a variedade do assunto e a gravidade do tema a tornassem agradável. (Maquiavel, 2006: 33-34).
Em outra passagem, refletindo sobre como um príncipe deve se relacionar com os súditos ou com os amigos, afirma:

[...] como sei que sobre isso muitos escreveram, receio, fazendo-o eu também, ser considerado presunçoso, principalmente porque, ao tratar deste assunto, me afasto das regras estabelecidas pelos outros. Mas sendo minha intenção escrever coisa útil, destinada a quem por ela se interessar, pareceu-me mais conveniente ir diretamente à efetiva realidade do que comprazer-me em imaginá-la. (Maquiavel, 2006: 101).

Maquiavel foi o primeiro a dar um sentido moderno ao conceito de "Estado", entendendo-o como um corpo político submetido a um governo e a leis comuns. Ele também foi o "profeta do moderno Estado nacional", caracterizado pelo

[...] poder central soberano e independente ao qual se subordinam todos os princípios de autoridade medieval, inclusive o religioso; se trata de um legislador que decide com autoridade nos assuntos internos e externos, isto é, uma ordem autônoma que não admite nada superior a ele e que tem o poder como atributo distintivo. (Várnagy, 2003: 19-20).

Um dos aspectos de sua modernidade reside no fato dele aceitar o desenvolvimento histórico como uma sucessão de causas concretas e não sobrenaturais, possíveis de serem compreendidas pelo homem possuidor da "virtud".

Para se entender parte da obra de Maquiavel, um outro elemento também se coloca como fundamental, que é aquele relacionado à construção dos Estados absolutistas na Espanha, na Inglaterra e principalmente na França. Estes acontecimentos sem dúvida serão decisivos na análise do florentino sobre a Itália, ainda marcada pela fragmentação em diversos Estados. Tal caráter fragmentário da península significava que nenhum Estado italiano era estável, pois qualquer cidade pequena podia ser atacada por algum vizinho poderoso. E estas cidades menores, por sua vez, quando conquistadas, frequientemente se rebelavam contra seus dominadores. Isso fazia com que a política na Itália renascentista fosse um espaço de constantes lutas entre os diversos Estados. E, segundo Maquiavel, o poder temporal da Igreja correspondia a um dos motivos para a realidade caótica da península, devido a sua insistência na fragmentação e a corrupção de suas ações. As cinco principais potências da península eram: o reino de Nápoles, os territórios da Igreja de Roma, a república de Florença, o ducado de Milão e a república de Veneza. Será tendo em vista essa realidade que Maquiavel desenvolverá a sua análise. 
E é justamente por isso que a sua obra não se coloca como uma construção metafísica, mas sim como uma importante "tradutora" da realidade objetiva da época. $\mathrm{O}$ “[...] seu pensamento teórico e a sua filosofia estão imersos na análise concreta do presente [...]" (Frosini, 2003: 163).

A sua abordagem, fazendo do príncipe e do homem,

[...] o autor de seu próprio destino é outra característica que mostra claramente seu alinhamento com a modernidade e expressa uma nova visão acerca da história, sendo o centro de sua meditação política a vontade humana, na qual o homem tem a possibilidade de modificar sua realidade e determinar seu destino [...] (Várnagy, 2003: 43)

Como o próprio Maquiavel afirma, num sentido de aconselhar o príncipe: quanto ao exercício do espírito,

[...] deve o príncipe ler a história, e nela considerar as ações dos grandes homens, ver como se conduziram nas guerras, examinar as causas das suas vitórias e derrotas, a fim de poder evitar estas e alcançar aquelas [...] (Maquiavel, 2006: 99).

Maquiavel entende a teoria política justamente como um ramo do conhecimento possível de ser entendido por meio da própria história e pela experiência concreta dos fatos. Em seu $O$ Príncipe, isto fica explícito quando justifica seu presente a Lourenço de Médicis, dizendo:

[...] desejando apresentar-me a Vossa Magnificência com algum testemunho da minha vassalagem, não encontrei, entre as coisas do meu cabedal, nem uma que me seja tão cara ou que tanto considere quanto o meu conhecimento dos feitos dos grandes homens, por mim obtido através da longa experiência das coisas modernas e do continuado estudo das antigas [...] (Maquiavel, 2006: 33).

$\mathrm{Na}$ verdade, essa forma de entender a política está relacionada ao próprio movimento renascentista de fundação dos diversos ramos do conhecimento. Em outras palavras, Maquiavel faz com a política o que outros fazem com as artes, com a filosofia, com a física, com a música, com a medicina, etc. Ele acabou por construir uma linguagem própria para o entendimento de um determinado comportamento humano, ou seja, a política deveria ter suas próprias ferramentas de explicação do mundo. Eé justamente por sua escrita e por sua nítida separação da política em relação aos outros ramos do conhecimento que Maquiavel pode ser considerado o fundador do pensamento político moderno. Descobrindo a sua autonomia e instaurando um discurso empirista e realista,
[...] substituindo a imaginação pelos fatos, as prescrições pela descrição, fazendo uma análise objetiva da realidade com suas regras e escrúpulos, ao contrário de qualquer contaminação moralista. (Várnagy, 2003: 41).

A partir dessa perspectiva que ele vai depositar sua confiança nas ações do príncipe, em relação às soluções dos problemas da península. Em meio a um sentimento de angústia, expressa:

Assim, como que reduzida a um sopro de vida, a Itália espera por aquele que pense as suas feridas e ponha fim aos saques da Lombardia, aos tributos do reino e da Toscana, e cure as suas chagas há já tanto tempo enfistuladas. Vê-se que ela roga a Deus que lhe mande alguém que a vingue destas bárbaras crueldades e insolências; vê-se, ainda, que ela está pronta e disposta a seguir uma bandeira, desde que alguém a empunhe. Não se vê, neste momento, em quem possa ela mais esperar do que na vossa ilustre casa [...] (Maquiavel, 2006: 148).

A conquista do

Estado primeiramente, e a sua conservação posterior, constitui o elemento essencial da realização do ideal moral e político de Maquiavel, a redenção da Itália. (Bonadeo, 1969: 245).

Trazendo essa discussão para a análise presente nos Quaderni, tratava-se, então,

[...] para Gramsci, de retomar essa "autonomia" da política fundada por Maquiavel, procurando, a partir dessa definição, construir uma ciência da política como forma da filosofia da práxis, que tivesse como método uma "objetividade realista". A retomada do princípio da "verità effettuale della cosa”, com o qual Maquiavel pretendia abordar a política como ela é e não a sua imaginação e, desse modo, orientar uma prática política eficaz, assumia uma posição estratégica nesse empreendimento. (Bianchi, 2007).

Justamente pela força da ação política contida em $O$ príncipe, Gramsci verá no pensamento de Maquiavel o elemento nacional progressista da Itália no período renascentista. Nos Quaderni, o florentino será lido "com os olhos de político, não de acadêmico". (Portantiero: 149, 2003) Quando a ciência da política interage organicamente com a política. $O$ príncipe, por esse motivo, acaba surgindo como um tratado "político por excelência, que expressa sua dimensão política com toda clareza no apaixonado apelo do ultimo capítulo.” (Kanoussi, 2003: 140). 


\section{Maquiavel a partir dos Quaderni}

A Maquiavel, Gramsci dedicou um de seus "cadernos especiais", o de número 13, escrito entre os anos de 1932-34. Nele, o início das reflexões se dá com uma apreciação sobre o Príncipe.

O caráter fundamental do Príncipe é o de não ser um tratado sistemático, mas um livro "vivo", no qual a ideologia política e a ciência política fundem-se na forma dramática do "mito". Entre a utopia e o tratado escolástico, formas nas quais se configurava a ciência política até Maquiavel, este deu à sua concepção a forma da fantasia e da arte, pela qual o elemento doutrinário e racional personifica-se em um condottiero, que representa plástica e "antropomorficamente" o símbolo da "vontade coletiva". (Gramsci, 2001: 1555, Q. 13).

Aqui é possível perceber algumas características importantes da obra de Maquiavel como, por exemplo, o seu aspecto histórico - isto é, seu contato com a vida italiana - e também a sua tentativa de pensar um movimento que incorpore a "vontade coletiva". Segundo Gramsci, Maquiavel, em O Príncipe, ressalta - a partir de seu conhecimento teórico e de suas experiências práticas - diversas situações históricas e concretas envolvendo o poder políticosocial com o intuito de indicar a possibilidade de se formar uma "vontade coletiva" italiana. Portanto, a indicação fundamental feita pelo autor dos Quaderni está relacionada ao caráter histórico-concreto dos escritos maquiavelianos, intimamente ligados às questões centrais, da Itália e da Europa, de sua época. Bastante oposto às reflexões escolásticas, muito frequientes em seu tempo, caracterizadas pelo distanciamento frente aos principais problemas vividos pelos italianos.

Sobre a categoria "mito", o autor dos Quaderni a retira da obra de Georges Sorel. Como ele mesmo explica:

O Príncipe de Maquiavel poderia ser estudado como uma exemplificação histórica do "mito" soreliano, isto é, de uma ideologia política que se apresenta não como fria utopia nem como raciocínio doutrinário, mas como uma criação da fantasia concreta que atua sobre um povo disperso e pulverizado para despertar e organizar sua vontade coletiva. O caráter utópico do Príncipe consiste no fato de que o "príncipe" não existia na realidade histórica, não se apresentava ao povo italiano com características de imediaticidade objetiva, mas era uma pura abstração doutrinária, o símbolo do líder, do condottiero ideal; mas os elementos passionais, míticos, contidos em todo o pequeno livro, com movimento dramático de grande efeito, sintetizam-se e tornam-se vivos na conclusão, na invocação de um príncipe "realmente existente". (Gramsci, 2001: 1555-56, Q. 13).
Portanto, o príncipe de Maquiavel é uma síntese de utopia e história. Como se as condições concretas da Itália do século XVI, exigissem um sujeito histórico ainda não identificado na realidade. Desse modo, Maquiavel parte de uma determinada necessidade histórica - ou seja, a organização de uma vontade coletiva do "povo" - para então, visualizar o príncipe ideal. Um dos principais objetivos políticos da vontade coletiva que deveria ser despertada no interior do "povo", pelo príncipe, correspondia à fundação de um novo Estado - isto é, a monarquia absoluta.

Segundo Gramsci, o próprio Maquiavel personifica os desejos populares, sentindo-se parte integrante e consciente deles. Por esse motivo toda argumentação, presente no pequeno livro, não pode ter como origem outro espaço de realização senão a consciência popular, pois é a partir dela que o príncipe maquiaveliano ganha vida. Por meio da paixão, Maquiavel expõe os principais anseios do "povo" - que buscava um príncipe para encarná-los. E é justamente por seu caráter apaixonado e voltado a ação que o Príncipe pode ser entendido como um "manifesto político". Como diz o próprio Gramsci, o estilo de Maquiavel não é de forma alguma o de um tratadista sistemático, como os que a Idade Média e o Humanismo conheceram. Ele representa os anseios de um homem de ação, de quem quer induzir os indivíduos ao movimento real da vida. Resumindo, apresenta todo o aspecto energético necessário a um "manifesto de partido". (Gramsci, 2001, Q. 13).

Tal leitura, parte da própria elaboração de Maquiavel, caracterizada pela crítica ao presente, criando conceitos gerais que se apresentam sob forma aforística e não sistemática, e expressando

[...] uma concepção do mundo original, que também poderia ser chamada de 'filosofia da práxis' ou 'neo-humanismo', na medida em que não reconhece elementos transcendentais ou imanentistas (em sentido metafísico), mas baseia-se inteiramente na ação concreta do homem que por suas necessidades históricas opera e transforma a realidade. (Gramsci, 2001: 657, Q. 5).

Devido a essa relação com a realidade concreta, Gramsci o coloca como um formulador de uma "filosofia da práxis", o que, de certo modo, não restringe tal concepção, presente nos Quaderni, ao marxismo.

Maquiavel percebe que tanto a Comuna e a República quanto a Senhoria Comunal não podiam se transformar em um grande Estado. Isto porque lhes faltava, além de um território extenso também uma população suficiente para ser a base de uma força militar que permitisse uma política internacional autônoma. Maquiavel percebia que na Itália, em 
decorrência da presença do papado, fortalecia-se uma situação contrária a construção do Estado unitário. E este aspecto iria durar enquanto a própria religião não fosse vista também como uma questão política estatal, deixando de ser um problema exclusivo da fé e do Papa. A Igreja deveria ser impedida de intervir na vida política de povos por ela não dominados temporalmente, já que mesmo nestes locais o poder eclesiástico não levava em conta os interesses concretos dos Estados. Justamente por isso, as forças do poder papal poderiam ser concebidas como desagregadoras e não-nacionais. (Gramsci, 2001, Q. 5). A religião deveria, já naquele momento, ser enquadrada também como um programa político e o Papa como seu principal representante. Desse modo, a sua tática do "dividir para dominar" poderia ser questionada e obstaculizada de modo também político e laico.

Todavia, além do seu vínculo com a "realidade efetiva" italiana, marcada pela desagregação e fragmentação da sociedade, Maquiavel também estava atento aos acontecimentos internacionais. Gramsci situa historicamente o florentino como o "teórico do Estado unitário moderno; o pensador que reflete sobre a experiência do Estado unitário monárquico francês, espanhol, inglês e indica essa experiência à Itália como sendo o caminho para superar a crise que envolve a sociedade italiana." (Gruppi, 2000: 73) As monarquias absolutistas nacionais da Espanha e da França foram, portanto, experiências que lhe chamaram muita atenção, pois demonstravam a possibilidade histórica e concreta de se efetivar a unificação do poder estatal e do espaço territorial da própria península.

\section{Maquiavel diante da questão nacional italiana}

Ainda sobre a questão da "vontade coletiva", Gramsci busca desenvolve-la partindo de uma importante interrogação:

[...] quando é possível dizer que existem as condições para que se possa criar e se desenvolver uma vontade coletiva nacional-popular? (Gramsci, 2001: 1559, Q. 13).

Nela, um primeiro elemento fundamental a ser destacado é que o autor acrescenta um aspecto novo aliado à noção "vontade coletiva", materializado na categoria "nacional-popular" - ponto central para o aprofundamento do tema da nação em seu pensamento. Ligado a essa pergunta, Gramsci lança um outro questionamento: "Por que não se teve a monarquia absoluta na Itália na época de Maquiavel?"
(Gramsci, 2001: 1559, Q. 13). Portanto, é a partir dessas duas interrogações que o autor estabelece o vinculo entre a "vontade coletiva nacional-popular" e a monarquia absoluta, isto é, entre a "sociedade civil" e o "Estado". Outro ponto relevante encontrado aqui é que o cenário histórico-intelectual, a partir do qual surge o conceito "nacional-popular", refere-se ao século XVI e às idéias de Maquiavel.

De qualquer forma, para responder a tal conjunto de interrogações, Gramsci se utiliza de um método de análise fundamentalmente histórico, destacando as múltiplas relações entre passado e presente encontradas na estrutura social da península. Desse modo, ele afirma a necessidade de se voltar ao Império Romano, analisando as questões da língua, dos intelectuais, etc; à época das Comunas medievais para compreender suas funções e significados; ao catolicismo, entre outros elementos. Em suma, deveria se fazer um esboço de toda a história italiana, sintético, mas exato (Gramsci, 2001, Q. 13).

A preocupação latente neste momento da reflexão gramsciana, corresponde à tentativa de se compreender os motivos das derrotas das iniciativas direcionadas à criação de uma "vontade coletiva nacional-popular" na Itália. Aqui, então, Gramsci busca sistematizar algumas questões fundamentais para o entendimento não apenas da história italiana, mas do amplo e complexo tema da nação. Eé partindo dessa perspectiva que o tema da herança históriconacional - no caso da península, conservadora e anti-nacional - ganhará profundidade analítica nos Quaderni del Carcere.

Assim, a explicação da não consolidação de uma "vontade coletiva nacional-popular" na história italiana deveria ser encontrada na existência de determinados grupos sociais que se

[...] formam a partir da dissolução da burguesia comunal, no caráter particular de outros grupos que refletem a função internacional da Itália como sede da Igreja e depositária do Sacro Império Romano, etc. (Gramsci, 2001: 1559, Q. 13).

Esta particularidade italiana foi decisiva para o não surgimento da monarquia absoluta e para o não desenvolvimento da força "jacobina", séculos mais tardes, em seu território. O "jacobinismo" foi, na visão de Gramsci, um movimento fundamental na organização de uma "vontade coletiva nacionalpopular" - que criou na França as bases do Estado moderno (Reis, 2012).

Para Maquiavel, os principais exemplos de monarquias absolutas e unidades nacionais vinham dos territórios francês e espanhol. E para se inserir nesse processo histórico internacional, a Itália 
deveria voltar ao Império Romano, isto é, à sua própria história, não apenas para recuperar a poesia, a pintura e a escultura; a "virtù militar" também se colocava como indispensável para a sua vida social. Somente com uma milícia não mercenária, organizada e composta pela massa dos camponeses, a Itália poderia expulsar os estrangeiros e fundar a sua unidade estatal-territorial. E este era um aspecto que poderia sim ser buscado nos antigos. Então, na época renascentista, o principal teórico e defensor da criação de uma milícia de cunho nacional foi Nicolau Maquiavel. Com ela seria possível expulsar os estrangeiros e unificar, por meio da monarquia absoluta, os diversos Estados isolados.

O secretário florentino sugere precocemente a necessidade de se executar um movimento de "tradução" dos elementos progressistas tanto no âmbito da história da própria península, ressaltando e incorporando no presente certos aspectos do seu passado romano, quanto na esfera internacional, na qual a França e a Espanha se apresentavam como um horizonte histórico a ser alcançado.

Interessante notar que entre os intelectuais exportados pela península para o restante da Europa, o militar se destacava. E isso chama a atenção porque uma das principais características da formação militar se fundamenta justamente no elemento "nacional".

A burguesia das Comunas teve também uma origem militar "nacional", no sentido de que sua organização de

[...] classe foi originariamente também militar, e que foi através de sua função militar que conseguiu tomar o poder. Esta tradição militar se quebrou depois da chegada ao poder, depois que a Comuna aristocrata se tornou Comuna burguesa. (Gramsci, 2001: 383, Q. 3).

Gramsci ressalta ainda que Maquiavel foi um pensador do seu tempo, expressão italiana dos movimentos mais progressistas da Europa, isto também por compreender o significado histórico de determinados acontecimentos estrangeiros. Em $O$ Príncipe, o secretário florentino demonstra atenção tanto à vida interna da Itália, quanto aos eventos gerias da Europa. Por isso, o seu pensamento se liga diretamente às:

1) lutas internas da república florentina e da estrutura particular do Estado que não sabia libertar-se dos resíduos comunal-municipais, isto é, de uma forma bloqueadora de feudalismo; 2) lutas entre os Estados italianos por um equilíbrio no âmbito italiano, que era obstaculizado pela existência do Papado e dos outros resíduos feudais, municipalistas, da forma estatal citadina e não territorial; 3) lutas dos Estados italianos mais ou menos solidários por um equilíbrio europeu, ou seja, das contradições entre as necessidades de um equilíbrio interno italiano e as exigências dos Estados europeus em luta pela hegemonia. (Gramsci, 2001: 1572, Q. 13).

Desse modo, Maquiavel se coloca como um intelectual fundamental para o entendimento da questão nacional italiana. Afinal, ele não apenas percebe o inicio de um dos principais problemas da península - sua fragmentação política, territorial e econômica, em decorrência das forças feudais e religiosas - como também é um dos primeiros a tentar resolvê-lo. E este pode ser considerado como um importante legado deixado pelo autor florentino, isto é, o de pensar a construção de um movimento nacional progressista entre os italianos.

No decorrer do processo histórico da Itália, o problema da desagregação territorial, econômica e político-cultural, revelou-se decisivo para o não surgimento da "vontade coletiva nacional-popular". Problema, como se nota, já identificado pelo pensamento de Maquiavel - que significou uma importante luta contra os resíduos feudais, em nome das forças progressistas, guiadas pela burguesia urbana e comercial. Aliás, pode-se dizer que o intuito de Maquiavel, em seu $O$ príncipe, tenha sido justamente o de convencer tais forças da necessidade de haver um líder, um condottiero, não apenas consciente de seus objetivos, mas também preparado para conquistá-los.

No século XVI, a construção de uma monarquia absoluta na Itália, era o que tinha de mais avançado em termos históricos. Isto porque ela significava uma forma de regime popular, apoiada nos burgueses, artesãos e camponeses, contrapondo-se aos interesses fracionários da nobreza e da Igreja.

Comparando Maquiavel a Jean Bodin (filósofo francês também do século XVI), Gramsci ressalta que o último foi o fundador da ciência política francesa, num terreno político-social muito mais avançado e complexo, em relação ao oferecido pela Itália, ao primeiro.

Para Bodin, não se trata de fundar o Estado unitário-territorial (nacional), isto é, de retornar à época de Luís XI, mas de equilibrar as forças sociais em luta dentro desse Estado já forte e enraizado; não é o momento da força que interessa a Bodin, mas o do consenso. (Gramsci, 2001: 1574, Q. 13).

E, esta diferença, estava clara para Maquiavel, isto é, por mais que ele tivesse como exemplo de experiência histórica progressista a monarquia 
absoluta francesa, não deixou de perceber o processo particular pelo qual atravessava a Itália.

De acordo com Gramsci, o Estado unitário e a "vontade coletiva nacional-popular" não se formaram na península, no período de Maquiavel, pelo fato da burguesia não ter superado seu momento econômicocorporativo em direção ao espaço amplo da política. Os setores burgueses não se libertaram da concepção medieval-cosmopolita sustentada pelo Papa, pelo clero em geral e pelos intelectuais renascentistas. E, em sua leitura, Maquiavel somente defendeu a monarquia absoluta, pelo fato dele ter vivido a transição entre o Estado econômico republicano e o Estado monárquico absoluto. Em outras palavras, mesmo não se desvinculando da república, “[...] compreende que só um monarca absoluto pode resolver os problemas da época." (Gramsci, 2001: 724, Q. 6). Por possuir tal visão, Maquiavel representou a filosofia mais avançada da Europa daquele momento. Em conseqüência, acabou influenciando certos dirigentes políticos estrangeiros, de modo que o seu pensamento

[...] serviu realmente aos Estados absolutos em sua formação, porque tinha sido a expressão da 'filosofia da época', européia mais do que italiana. (Gramsci, 2001: 723, Q. 6).

Comparando Maquiavel a uma outra importante figura italiana do século XVI, Gramsci diz:

Guicciardini representou um passo atrás na ciência política em relação a Maquiavel. O maior 'pessimismo' de Guicciardini significa apenas isso, Guicciardini retorna a um pensamento político puramente italiano, ao passo que Maquiavel se havia elevado a um pensamento europeu. Não se compreende Maquiavel se não se leva em conta que ele supera a experiência italiana com a experiência européia (internacional, naquela época): sua "vontade" seria utópica sem a experiência européia. Por isso, a própria concepção de "natureza humana" nos dois é diferente. Na "natureza humana" de Maquiavel está incluído o "homem europeu"; e este homem, na França e na Espanha, superou efetivamente a fase feudal desagregada com a monarquia absoluta: logo, não é a "natureza humana" que se opõe ao surgimento, na Itália, de uma monarquia absoluta unitária, mas condições transitórias que a vontade pode superar. (Gramsci, 2001: 760, Q. 6).

Então, quando Maquiavel defende a unidade italiana, suas ideias estão ligadas também aos acontecimentos gerais da Europa. E, essa sua capacidade de "traduzir" o "mundo" para a península, deu-se mesmo estando inserido numa realidade social muito avessa ao seu pensamento. Todavia, esse pode ter sido justamente o motivo pelo qual conseguiu enxergar mais longe, quando comparado aos seus contemporâneos. $\mathrm{O}$ fato dele ter vivido no centro do Renascimento fez com que sua crítica se tornasse mais profunda. À medida que inseria a história particular da península no contexto europeu, ele identificava melhor o processo social anti-popular pelo qual percorria a Itália.

$\mathrm{Na}$ análise gramsciana, o principal movimento político-cultural oposto ao renascentista foi a Reforma protestante, iniciada na Alemanha também no século XVI. E esta Reforma será justamente a concretização daquela "vontade coletiva nacional-popular" buscada, mas não vista, por Maquiavel, morto anos antes.

Sobre os movimentos que impulsionaram as reformas da Igreja Católica, Gramsci defende que eles sinalizavam um maior interesse do "povo" pelas questões culturais e um maior interesse por este por parte de grandes personalidades religiosas, ou seja,

[...] os intelectuais mais em evidência da época: mas também eles, pelo menos na Itália, são ou sufocados ou domesticados pela Igreja, enquanto em outras partes da Europa se mantêm como fermento, até desembocar na Reforma. (Gramsci, 2001: 642, Q. 5).

Martinho Lutero pode ser identificado como um dos intelectuais que, por estar fora da Itália, conseguiu desenvolver mais profundamente ideias contrárias à Igreja de Roma. Como na península a religião não era um elemento de coesão entre o "povo" e os intelectuais, a crise filosófica gerada pela Reforma não criou nas classes populares uma vontade coletiva. Na Itália, o enfraquecimento da Igreja não se originou do seu "povo", porque não havia um "bloco nacional-popular" no campo religioso. Na sociedade italiana não existia uma "igreja nacional", mas um cosmopolitismo religioso, pois os seus intelectuais estavam imediatamente ligados a toda a cristandade internacional, como dirigentes não-nacionais. O que significava o predomínio da separação entre ciência e vida, entre religião e vida popular, entre filosofia e religião. Assim, "[...] os dramas individuais de Giordano Bruno, etc, pertencem ao pensamento europeu e não ao italiano." (Gramsci, 2001: 1130, Q. 9).

A crítica de Gramsci ao Renascimento italiano, em alguns momentos, é exposta de forma bastante contundente. Para ele, o Humanismo e o Renascimento podiam ser considerados como reacionários, pelo fato de fortalecerem a derrota da nova classe e negarem o aspecto econômico que também nascia (Gramsci, 2001, Q. 8). Aqui, então, afirma-se, de modo radical, que o movimento renascentista, influenciado 
fundamentalmente pela concepção cosmopolita e antinacional da Igreja, não assimilou à sua cultura todo o desenvolvimento econômico-social da burguesia. Em outras palavras, o humanismo representou a separação entre os intelectuais o as massas populares que se nacionalizavam, interrompendo o processo de formação político-nacional da Itália para retornar à velha posição do cosmopolitismo imperial e medieval. Desse modo, distanciou-se do movimento históricoeuropeu que sinalizava a possibilidade de promover na península a unificação territorial e nacional.

Para melhor compreender esse processo podem ser ressaltadas as seguintes questões: quais os motivos que levaram a existência de figuras como Michelangelo e Leonardo Da Vinci quase somente na Itália? Porque para eles, a política não era compreendida da mesma forma que a arte? Para Gramsci aqui estava presente um dos problemas centrais, isto é, era preciso " $[. .$. observar, na vida desses artistas, como se destaca sua anacionalidade." (Gramsci, 2001: 258, Q. 2). No entanto, em certo sentido, o autor italiano até insinua uma determinada inevitabilidade do "espírito artístico" anti-nacional sobre a subjetividade histórica da época. Na seguinte exposição, isso fica claro: "E, em Maquiavel, o nacionalismo era suficientemente forte para superar o 'amor à arte pela arte'? Uma investigação desta natureza seria muito interessante: o problema do Estado italiano interessava Maquiavel mais como 'elemento nacional' ou como problema político interessante em si e para si...?" (Idem) Portanto, Gramsci, em certos momentos, expõe diversos questionamentos aos seus problemas de pesquisa. No caso da suspeita levantada sobre Maquiavel, o autor dos Quaderni não parece acreditar na hipótese fundada na separação entre "política" e vida nacional italiana. A maior parte de seus comentários sobre o Secretário Florentino demonstra isso.

Recorrendo a De Sanctis, argumenta Gramsci que no movimento renascentista predominou as cores sombrias da corrupção política e moral e "[...] apesar de todos os méritos que se possam reconhecer ao Renascimento, ele desmanchou a Itália e a deixou como serva do estrangeiro." (Gramsci, 2001: 1909, Q. 17). Em poucas palavras, o humanismo pode ter representado um processo progressista para as classes cultas e cosmopolitas, mas, para as classes populares e para a vida nacional, significou um retrocesso.

Ao contrário disso, Maquiavel, entendendo o movimento histórico da época, lançou-se à tarefa de alertar não apenas o príncipe, mas também as classes populares, sobre a necessidade da unidade. Ele considerava ser tão urgente a criação do Estado unitário nacional que todos deveriam aceitar, para atingir esse importante fim, o emprego dos determinados meios (Gramsci, 2001, Q. 14). Maquiavel também quis educar o "povo", quando tenta convencê-lo e conscientizá-lo da existência de uma política realista capaz de alcançar um fim objetivado. Seguindo essa argumentação, diz Gramsci, ao analisar o autor de $O$ príncipe, era

[...] preciso cerrar fileiras e obedecer exatamente aquele príncipe que emprega tais métodos para alcançar o fim, porque só quem almeja o fim almeja os meios adequados para alcançá-lo. (Gramsci, 2001: 1691, Q. 14).

No caso do fundador da ciência política moderna, o fim era a construção da monarquia absoluta, como forma de limitar a fragmentação feudal, o poder dos padres e dos estrangeiros; o meio seria a efetivação da "vontade coletiva nacional-popular" - fundada nas classes populares e na construção de um exército nacional, permanente e centralizado.

Nos séculos XV-XVI, e até mesmo depois, existiram bons capitães, condonttieri, com desenvolvimento notável na tática e na estratégia, no entanto, não conseguiram criar um exército nacional, devido à separação entre o "povo" e as "classes dirigentes". (Gramsci, 2001, Q. 2) Maquiavel foi o principal autor a compreender, na Itália, a impossibilidade de haver um verdadeiro Renascimento, sem a fundação de um Estado nacional. Por isso, ele acabou sendo o teórico dos acontecimentos ocorridos fora da península. (Gramsci, 2001, Q. 17)

Gramsci afirma ainda que, no período do Renascimento, a "grande política", isto é, a capacidade de se compreender o processo histórico, em suas grandes transformações e inovações, era efetuada pelos italianos somente no âmbito do exterior, de modo cosmopolita, ao contrário do que era efetivado na sua vida interna, basicamente a "pequena política". Na península, predominava a estreiteza programática (corporativismo) e a política mesquinha, do dia-dia. Com o fim do período de ampla ligação dos intelectuais italianos com a Europa, a "grande política" também desapareceu, restando apenas a "pequena política", realizada no plano nacional. A tarefa, então, deveria ser a de organizar um movimento coletivo sustentado na "grande política", mas tendo como base o "povo-nação" (Gramsci, 2001, Q. 15), eliminando a concepção municipal-corporativa - importante obstáculo para a unidade italiana.

Portanto, Gramsci, além de identificar o caráter político-cultural dos intelectuais do Renascimento, estranho à vida nacional, também aponta os desdobramentos problemáticos de tal postura para a histórica italiana. Neste sentido, enquadra a debilidade 
na criação de uma formação nacional italiana, também devido à predominância da "pequena política". Além do mais expõe a dificuldade e a complexidade que foram surgindo ao longo da história da península para se construir um amplo movimento intelectual e moral hegemônico capaz de entender o mundo a partir do "nacional-popular".

Sobre os assuntos internos italianos, a exceção no Renascimento, como já foi destacada, certamente fora Maquiavel. Este pensou a "grande política" para a Itália, objetivando a fundação de um novo Estado unitário. Estabeleceu uma clara relação entre nacional/ internacional e a partir dela conseguiu perceber a possibilidade de se construir a unidade na península. O florentino foi um grande "tradutor" para o território italiano dos movimentos progressistas e populares "mundiais". E esta é uma referência teórica e política decisiva para o pensamento gramsciano, ajudando a fortalecer ainda mais uma postura intelectual já vista no período pré-carcerário.

A experiência francesa teve uma influência especial sobre as concepções maquiavelianas. Refletindo uma passagem de $O$ Príncipe - quando Maquiavel cita um episódio, no qual afirmou a um Cardeal francês que os franceses não entendiam de Estado, na tentativa de devolver a acusação segundo a qual os italianos não entendiam de guerra - o autor dos Quaderni ressalta que ela isoladamente não tem nenhum significado. Tal passagem em nada diminui o entusiasmo de Maquiavel sobre a forma como os franceses conduziam sua política. Em outras palavras, Maquiavel estava bem longe de pensar que os

[...] franceses não entendiam de Estado, até mesmo porque admirava o modo pelo qual a monarquia (Luis XI) realizava a unidade estatal da França e fazia da atividade francesa de Estado um termo de comparação para a Itália. (Gramsci, 2001: 657, Q. 5)

Tendo em vista a França de séculos posteriores, mais precisamente da revolução burguesa, Gramsci estabelece a seguinte relação entre Maquiavel e a tradição política deste país:

Há em Maquiavel a 'paixão' do 'jacobino' e, por isso, ele agradaria tanto os jacobinos e aos iluministas: este é um elemento 'nacional' em sentido próprio e deveria ser estudado preliminarmente em toda pesquisa sobre Maquiavel. (Gramsci, 2001: 1929, Q. 17).

Ao expressar esta "precocidade" quanto à "paixão do jacobino", o Secretário Florentino também acaba por indicar, ainda no século XVI, a importância do "sentimento nacional" - tanto para a fundação do novo Estado, quanto para a unidade política, cultural e militar da "nação" moderna. (Medici, 2007) Os reformadores da Igreja Católica, também sinalizaram a relevância do "nacional" para qualquer atuação política e de massas, no período histórico que se inaugurava.

Importante notar que a França não foi referência progressista somente para Maquiavel, a sua tradição político-cultural continuou exercendo influência sobre a teoria política italiana, agora a gramsciana. Para o autor dos Quaderni, um dos principais espaços em que o "nacional-popular" foi levado à frente, correspondia justamente ao "jacobinismo".

\section{Considerações Finais}

Maquiavel, como foi possível perceber, é visto por Gramsci como um autor fundamental não apenas para a ciência da política em geral, mas também para se pensar o tema nacional italiano. A sua precocidade jacobina contribuiu para o autor dos Quaderni compreender a profundidade histórico-social da questão nacional italiana. E as observações feitas por Gramsci sobre a relação entre Maquiavel e o problema da unificação, certamente, interfere em suas anotações sobre a hegemonia, os intelectuais, o partido político, as classes subalternas, etc. Em outras palavras, não se tem compreensão global das ideias do autor sardo/ italiano sobre os intelectuais cosmopolitas ou sobre o partido político enquanto organizador de uma vontade coletiva, por exemplo, sem perceber a ponte que ele estabelece entre o pensamento maquiaveliano e os problemas concretos vividos pelos italianos no Renascimento.

Longe de ser uma discussão isolada e de pouca importância para o pensamento político contemporâneo, as reflexões gramscianas, acerca da problemática Maquiavel/questão nacional, contribuem significativamente para um melhor entendimento do partido político, da sociedade civil, do Estado, dos intelectuais, da hegemonia, entre outros temas bastante caros à teoria política atual. Como afirma Guido Liguori:

[...] em todo pensamento de Gramsci, a reflexão sobre o Estado-nação é central e está intrinsecamente ligada ao tema da hegemonia. (Liguori, 2007: 67).

Foi seguindo tal raciocínio que o presente texto buscou se desenvolver, isto é, tentou contribuir não apenas para o debate em torno de uma questão específica de Gramsci, mas para uma discussão mais abrangente de seu pensamento e de certos temas centrais da teoria política contemporânea. 


\section{Referências}

Bianchi, Álvaro. 2007. Croce, Gramsci e a autonomia da política. Revista de Sociologia e Política, 29: 15-30.

Bonadeo, Alfredo. 1969. Appunti sul concetto di conquista e di ambizione nel Machiavelli e sull'Antimachiavellismo. Istituto Universitario Orientale, Annali-Sezione Romanza, 11(2): 245-260.

Frosini, Fabio. 2003. Gramsci e la filosofia - saggio sui Quaderni del cárcere. Roma: Carocci.

Gramsci, Antonio. 2001. Quaderni del cárcere. Torino: Einaudi, Edizione critica dell'Istituto Gramsci - A cura di Valentino Gerratana. 4 v.

Gruppi, Luciano. 2000. O conceito de hegemonia em Gramsci. Rio de Janeiro: Graal.

Kanoussi, Dora. 2003. Maquiavel nos Cadernos do cárcere. In C. N. Coutinho e A. de P. Teixeira (orgs.), Ler Gramsci, entender a realidade. Rio de Janeiro: Civilização Brasileira, p. 139-146.
Liguori, Guido. 2007. Roteiros para Gramsci. Rio de Janeiro: UFRJ.

Maquiavel, Nicolau. 2006. O príncipe. São Paulo: Cultrix.

Medici, Rita. 2007. Giacobinismo. In F. Frosini e G. Liguori (orgs.), Le parole di Gramsci - per um lessico dei Quaderni del cárcere. Roma: Carocci / International Gramsci Society - Italia, p. 112-130.

Portantiero, Juan Carlos. 2003. Gramsci, lector de Maquiavelo. In T. Várnagy (org.), Fortuna y virtud en la república democrática - ensayos sobre Maquiavelo. Buenos Aires: Clacso, p. 149-154.

Reis, Claudio. 2012. Reforma protestante e jacobinismo nos Quaderni del carcere: exemplos do "nacionalpopular". Revista Aurora, 5(Edição Especial): 91-102.

Várnagy, Tomás. 2003. Introducción. In T. Várnagy (org.), Fortuna y virtud en la república democrática - ensayos sobre Maquiavelo. Buenos Aires: Clacso, p. 9-52. 